症で，全株枯死するような被害を受けたものが少なかっ たためと考えら机る。

薬慧については目に見える茥葉の薬書斑，変色などは 㤎めら狆なかった。

子のう胞子の発芽におよほす薬剤の影響は第 4 表のと おりで，子のう胞子の発芽抑制度はスクレックスが最も 高く，次いでレジサンであった。ベンレート，トップジ ンは発芽の阻等打は以上 2 薬猎に比べて極めて低かっ た。このことをほ場での防除効果と関連させて考无ると レジサン，スクレックスについてはその㑯问がよく一致 するが，ベンレート，トップシンについては，ほ場での 効果の割には in vitroでの効果が低かった。このこと からベンレート，トップジンの効果は単に殺菌効果のみ に期することはできないようで，薬剤が菌の新陳代謝を 乱し病原打を低下させるか，あるいはナ久植物体に抵 抗打を与えるような方向に作用するのではないかとも考 えられるが，この点についてはさらに詳しく検討する必
第 4 表 子のう胞子の発芽におよぼす蒋 剂の種類および濃度

( 3 反復の平均)

(1969)

\begin{tabular}{|c|c|c|c|c|}
\hline 薬 剂 & 0.1 & 0.01 & 0.001 & 0.0001 \\
\hline ベンレート & 84.5 & 96.4 & 91.7 & 92.9 \\
\hline スクレックス & 0 & 89.9 & 95.4 & 96.9 \\
\hline トップジン & 87.2 & 86.4 & 92.5 & 95.2 \\
\hline 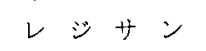 & 44.0 & 95.8 & 94.4 & 95.8 \\
\hline 標準(殺菌水) & \multicolumn{4}{|c|}{93.9} \\
\hline
\end{tabular}

注：表中数字は子のう胞子発芽率 $(\%)$

要がある。

以上のことからベンレート，スクレックス，トップジ ンは菌核病防除効果が高く, 目に見えるような莧害や収 量に及ぼす曹影響も芫られないことが明らかになった。

\title{
サッマイモ黒斑病防除薬凨のスクリーニング法
}

$$
\text { 木 村 貞 夫 (長崎県総合農林試験場) }
$$

\section{Simplified screening method of fungicides against the black rot of sweet potato, Ceratocystis fimbriata (Ellis et Halsted) Elliot, using sweet potato slices}

Sadao Kimura (Nagasaki Agr. \& Forest Exp. Sta.)

Sweet potato slices, $7-10 \mathrm{~mm}$ thick, were dipped in suspension of wettable powder at room temperature for 15-20 minutes, and then inoculated with filter paper discs (5mm dia.) containing black rot spores.

In case of less effective fungicides, colonies of $C$. fimbriata developed in 3-6 days under the condition of $25^{\circ} \mathrm{C}$ and high humidity. But, no colonies developed on sweet potato slices treated with Benlate, methy 1-1-(butyl-carbamoyl)-2-benzimidazole carbamate, at the concentration of $0.1 \%$.

In the field test as well as in this screening, Benlate was the most effective.

This simplified method will be practical for screening of fungicides to control the black rot of sweet potato.

サツマイモ黒斑病の防除楽凨として，これまで有機水 銀剤が用いられてきたが，水銀剂の使用規制によりしだ いに入手困難になってきている。また，これに代わる薬 剂も未だ明らかではない。これまでに，鉄塚らり2)，後 藤ら ${ }^{3 / 4) 5(6)}$, Daines ${ }^{7}$, 森ら ${ }^{8)}$ な゙により苗, あるいは塊 根を用いて黑玨病に対する有効薬剤の検索が行なわれた が，水銀剤以上のものは見出されていない。そこで，筆 者は殺菌㶡の抗菌力检定法の一種，乃紙盤付着法" 考にしてサツマイモのスライスを用いる簡易検定法を考 案し，市販農薬についてスクリーニングを試みた。さら に，ほ場試験によってその実用性を検討したので，ここ にその概要を翢告する。

本試験をとりまとあるにあたり，当場環境部長高木㓐
夫博士，同発生予察科長吉岡恒氏，研究買永野道昭氏か ら助言をいただいた。供試薬剂については，同病害虫科 長楩口泰三氏，研究䁲新須利則氏，中須賀孝正氏の御協 加を得た。また，農林省農㢦試験場作物第 5 研究室竹股 知久技官にはサツマイモ片による黒玟菌の培養法を御教 示いただき，本試験のヒントを得た。さらに，日本植物 防疫協会後藤和夫博士は貴重な文献を御患送下さった。 ここに記して，恶謝の意を表する。

\section{材 料 と 方 法}

1. 薬剂スクリーニング試験

屋内貯蔵の健全ないもを水洗し，70\%アルコールで拭 いて表面殺菌したのち，いもを輪切りにして，憬さ 7 
10mmのサツマイモ・スライスを準備した。これを, 所定 濃度の供試薬液に15～20分間浸漬 (液温 $17^{\circ} \mathrm{C}$ ), 約 1 時間 風乾して㓕菌シャーレに入れた。シャーレには殺菌水を 含ませた脱脂綿球を入れて湿室とした。あらかじめ, 黒
斑病菌胞子を付着させた直径 $5 \mathrm{~mm} の$ 和紙，またはろ紙円 盤を白金耳で釣菌し，サッマイモ・スライス上に接種し た。これを $22 \sim 25^{\circ} \mathrm{C}$ 定温器に保ち，3〜 6 日後に発病数 を調査して供試薬剤, 濃度の抗菌力を判定した(第 1 図)。

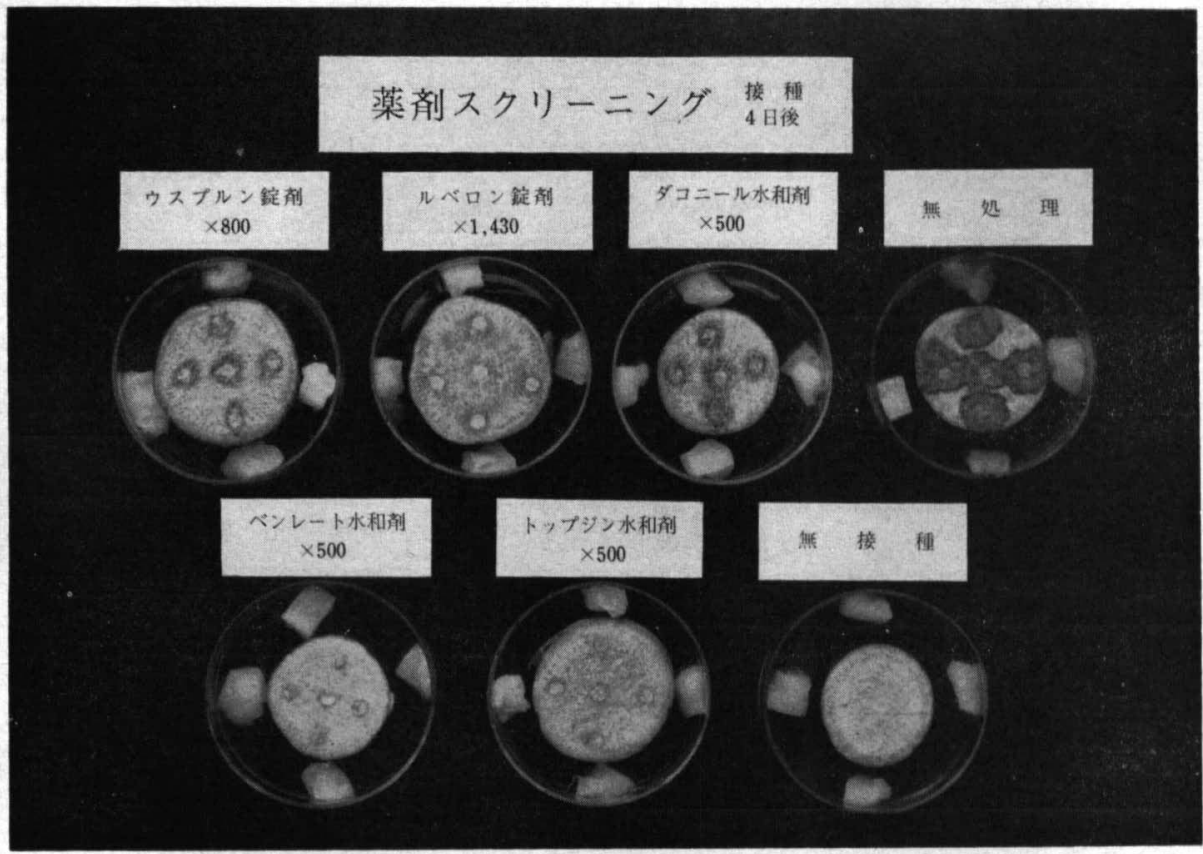

第 1 図 サツマイモ・スライスを用いた薬剤スクリーニング法

1 区 1 スライス， 5 カ所接種， 4 反復した。供試菌は 長崎県南松浦郡富江町産病いもから1968 年 2 月に分離 し, PDA 培地に継代培養し，植え継いで 2 週間培養し たものを用いた。サツマイモは䍜病性品種の農林 2 号を 用いた。

\section{2. 薬剂防除試験}

品種農林 2 号を用い，苗の切口から 10 1 $15 \mathrm{~cm}$ までの部 分を約 10 分間胞子浮遊液に浸漬接種した。薬剤処理は, 各薬剤とも接種 2 時間前, 2 時間後, 24 時間後の 3 区に 分けて所定濃度の薬液に浸漬（15２0分）して行ない, 処理後ただちに植え付けた。1区 1 ね ね，16本植え(3.5 $\left.\mathrm{m}^{2}\right)$ とし， 3 反復で行なった。 7 月 6 日に插苗し，10月 28日に収穫，1区10株について発病調査をした。

\section{試 験 結 果}

1. 薬剂スクリーニング試験

サツマイモ・スライスを用いて殺菌剤 21 種類, 殺虫剤 5 種類の抗菌力を検定した結果は第 1 表に示すとおりで ある。水銀剤のうち, ウスプルン 800 倍処理は接種して 3 日後に発病率 $100 \%$ に達した。ルベロン 1,430 倍処理は 接種 6 日後にも菌そうの発生をみとめなかったが，スラ
イス表面は青黒く污れ薬害症状を呈した。ベンレート， トップジン, NF-44 の500倍処理区は接種 6 日後にも発 病をみとめず，抗菌力の高いことを示した。なおこれ らの処理区で，接種部分のサツマイモ組織はわずかに褐 変したが，菌糸の組織内侵入をみとめなかった。マンネ ブダイセン 400 倍, ベジタ水和剤 500 倍処理はやや効果が みとめられたが，ダイセン以下 13 種類の殺菌剤の抗菌力 は低くかった。殺虫剤 5 種類を試みに検定した結果は, いずれも黒斑病菌に対してほとんど抗菌力のないことを 示した。

\section{2. 薬剤防除試験}

品種農林 2 号を用い, 苗の切口に接種し 3 種類の薬剤 に浸漬してその防除効果を調査した結果は第 2 表に示す とおりである。ウスプルン 800 倍処理は，接種前処理区， 接種後処理区ともに苗の発病率が高く，防除効果はみと められなかった。トップジン 500 倍処理は，接種 2 時間 前の薬剂処理では苗の発病を抑制したが, 接種後の処理 には効果をみとめなかった。ベンレート500倍処理は, 接種 2 時間前および 2 時間後の処理では防除効果が高く 苗の発病を抑制したが，接種24時間後の処理区では効果 の低下がみられ，60\%の苗発病率を示した。 
第 1 表 サツマイモ黒琵病防除楽㘊 スクリーニンゲ試験所續

\begin{tabular}{|c|c|c|c|}
\hline \multirow{2}{*}{ 供 試 薬 剂 } & \multirow{2}{*}{ 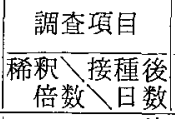 } & \multicolumn{2}{|c|}{ 発病率 } \\
\hline & & 3 日 & 6 日 \\
\hline ウスプルン 銫 郕 & $800^{\text {倍 }}$ & 100 & $100^{\%}$ \\
\hline ル ベ ロ ン " & 1,430 & 0 & 0 \\
\hline ダ イ 七 ン 水和㓮 & 400 & 100 & 100 \\
\hline マンネブ・ダイセン " & 400 & 65 & 85 \\
\hline ビスダイセン " & 400 & 100 & 100 \\
\hline ポマゾール「エフ」 & 500 & 100 & 100 \\
\hline ベジタ & 500 & 0 & 50 \\
\hline ダコ & 500 & 100 & 100 \\
\hline オーソサイド & 250 & 70 & 100 \\
\hline ダイホルタン & 500 & 100 & 100 \\
\hline$N F-44$ & 500 & 0 & 0 \\
\hline トップシン & 500 & 0 & 0 \\
\hline ベン $レ-1$ & 500 & 0 & 0 \\
\hline アントラコール & 400 & 100 & 100 \\
\hline ユ一パレン & 500 & 75 & 100 \\
\hline サ $=$ パ - & 500 & 100 & 100 \\
\hline スクレックス & 500 & 100 & 100 \\
\hline レ ジ サ ン & 500 & 100 & 100 \\
\hline ブラエス乳剂 & 500 & 0 & 85 \\
\hline 力 万 $₹$ C 水和剤 & 500 & 100 & 100 \\
\hline ボリオキシンA L＂＂ & 500 & 100 & 100 \\
\hline ダイアジノン & 500 & 100 & 100 \\
\hline エ ル サ ン & 500 & 100 & 100 \\
\hline バッ & 500 & 100 & 100 \\
\hline DDVP & 500 & 100 & 100 \\
\hline サッ セ ン & 500 & 100 & 100 \\
\hline 理 & 接 & 100 & 100 \\
\hline . & 無 接 種 & 0 & 0 \\
\hline
\end{tabular}

考

察

サツマイモ黒斑病防除薬剤としての水銀剂に代替する 薬剤を見出すために，サッマイモ・スライスを用いて市 販農薬26種類の抗菌力を検定した。その結果，水銀剤の ルベロン錠昘 1,430 倍处理以外にベンレート，トップシ ン， NF-44 水和剤の500倍処理が有効であることをみと めた。そこで，ほ場㑉験によりウスプルン 800倍，およ びベンレート，トップジン500倍の処理効果を検討した。 ウスプルン 800倍処理は防除効果が低くく，これまでの 成績と一致した。トップジン500倍処理は，サッマイモ。 スライスによる検定結果と異なり，接種後処理区で苗の 発病率は 100\%に達し効果をみとめなかった。ベンレー
第 2 表 サッマイモ黒玟病薬剂防除試験成綨

\begin{tabular}{|c|c|c|c|c|c|c|}
\hline 佔 試 樂 骫 & 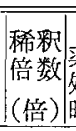 & 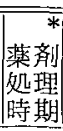 & \begin{tabular}{|l|} 
苗発 \\
苪率 \\
$(\%)$ \\
$\%$
\end{tabular} & 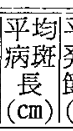 & 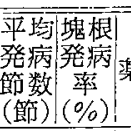 & \\
\hline ウスプルジ 鉒 剤 & 800 & $\begin{array}{l}\text { A } \\
\text { B } \\
\text { C }\end{array}$ & \begin{tabular}{r|}
93 \\
100 \\
100
\end{tabular} & \begin{tabular}{|l|}
4.5 \\
3.8 \\
7.6
\end{tabular} & \begin{tabular}{|l|l|}
0.9 & 12.1 \\
0.4 & 12.3 \\
1.3 & 18.9 \\
\end{tabular} & \\
\hline トップジン水和剂 & 500 & $\begin{array}{l}\text { A } \\
\text { B } \\
\text { C }\end{array}$ & \begin{tabular}{r|}
33 \\
100 \\
100
\end{tabular} & $\left|\begin{array}{l}2.0 \\
6.0 \\
6.4\end{array}\right|$ & \begin{tabular}{|r|r|}
0.5 & 9.7 \\
1.3 & 13.3 \\
1.4 & 13.4 \\
\end{tabular} & \\
\hline ベンレート水和剤 & 500 & $\begin{array}{l}\mathrm{A} \\
\mathrm{B} \\
\mathrm{C}\end{array}$ & $\begin{array}{r}0 \\
7 \\
60\end{array}$ & \begin{tabular}{|r|}
0 \\
0.2 \\
3.3
\end{tabular} & \begin{tabular}{|r|r|}
0 & 1.8 \\
0.0 & 3.2 \\
1.0 & 14.8 \\
\end{tabular} & - \\
\hline 処 & 接 & 種） & 100 & 7.3 & \begin{tabular}{|c|c|}
1.9 & 16.5 \\
0 & 3.8 \\
\end{tabular} & \\
\hline
\end{tabular}

注：薬刜処理時期：A …接種 2 時間前浸濾処理

$\mathrm{B} \cdots$ 接種 2 時間後

C...接種24時間後

ト500倍処理では, 接種前と, 接種 2 時間後の処理区で 顕著な防除效果をみとめたが，接種24時間後の処理では 防除效果の低下がみられた。この理由としては, 先に行 なった試験結果 ${ }^{10}$ によると黒臌病菌胞子をサッマイモ・ スライスに接種して 2 時間経過すると発芽しはじめ，24 時間後には内生胞子が新生することから，苗の組織中に 侵入した菌系に対してはベンレートの効果が及ばないの ではないかと考えられる。

試験例はわずかであるが，ほ場試験の結果からサツマ イモ・スライスを用いた簡易検定法の有効性について考 察すると, ウスプルンの場合にみられるように本法で抗 菌力の低い薬剤を除外することができるようであり，有 効樂剤についてのみ洼場試験に移してその效果を確認す ればよく，簡易で实用的な方法といえよう。

\section{摘}

（1）サッマイモ黒斑病に対する菜威の防除効果を検 定するために，愿さ $7 〜 10 \mathrm{~mm}$ のッマイモ・スライスを 所定濃度の供試薬液に浸䟺，風乾後，黑斑病菌を接種 し，薬剤の効果を調査した。

（2）本法により，高い抗菌力のみられたベンレート 水和剤500偣, トップジン500倍および，抗菌力の低くか ったウスプルン 800 倍処理によりほ場試験を行なった。 その結果，ベンレートの接種 2 時間前および 2 時間後処 理の防除効果は顕著であったが，24時間後处理では効果 の低下がみられた。ウスプルンとトップジン処理の効果 は低くかった。

（3）試験結果から,サツマイモ・スライスを用いた 
簡易検定法により抗菌力の低い薬剤を除外することがで き, 有効楽骫についてのみほ場試験を行なってその効果 を確認すればよく，本法は，簡易で実用的である。

\section{引用 文 献}

1）䤵塚喜久治 - 伊藤卓夫 (1939)：病虫害雑誌，26(3), 8-14 2) 鈋塚喜久治 - 伊藤卓夫 (1948)：愛知農試㓣立 60 周年記念策報, $113-120 \quad 3)$ 後藤和夫 $(1938-1943)$ ：
酒精原料作物指定䧕験成績 病害の部 4) 後藤和夫 (1945)：農業及園芸, 20, 147-150 5) 後藤和夫 (1951):

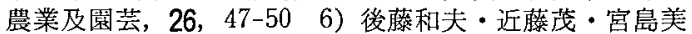
智男 (1949): 農業電化, 2(6), 7-11，16 7) Daines, R. H. (1959): Phytopath., 49, 249-251 8) 森寛一. 池上雍春 (1961)：関東東山病虫研会報，8，23 9）古山 清 - 营原寬夫 (1965)：農薬の生物㛟定法 10) 木村面 夫・吉岡恒 (1971)：病害虫試験成續書, 長崎総茇, 4548

\section{チャの主要病害に対する薬郕の作用性に関する研究（第 2 報） \\ 炭そ病に対する薬郕の作用について}

\section{野 中 寿之(毞児島景茶業試娩場)}

笋者は先報でベノミル，チオファネート両水和剤が岸 そ病に対して感染後の潜伏期散布でも発病を阻止する治 療効果を有することを報告し，従来の予防を主体とする 防除とは異なる治療的な防除法の可能性があることを明 らかにしたが，今後もこのような新しい作用型の梖剤が 開発されてくるものと予想される。

このため今後の防除は蒋剤の作用性を十分解析し，そ れにかなった使用体系を確立することが必要と思和れ る。

このような背景から十数種の殺菌剤について，キャの 炭そ病に対する作用性を検定したのでその結果を報告す る。

\section{試験方法および結果}

薬剤の作用性検定

本病は園队の越冬病葉が第 1 次伝染源となり，これに
形成される分生胞子によって新来に伝染し，潜伏期闆 2 ３週間を経て発病し，その後は新しい発病葉が伝染源 となり伝染・発病をくりか无すが，このような有病の発 生環の中で薬剂の作用機作としては伝染源病葉の胞子形 成阻止作用，病原菌の侵入を防止する予防作用および感 染後の治療作用が考えられるため，昭和 44 と 45 年の 2 力 年に19種の殺菌剤のこのような作用効果について検定し た。

\section{（1）病葉の分生胞子形成阻止效果}

ほ場から採集した越冬病葉20葉を供試薬液に数秒間浸 漬, 風乾後, 水浸滤紙を入れたシャーレに納め $27^{\circ} \mathrm{C}$ の状 態で5 日間おいたのち遊出法で胞子を取出し，オリンパ スE $10 \times 40$ で視野を鏡検し，胞子の形成量をしらべた。 各薬剤の分生胞子形成阻止效果は第 1 表に示すとおりで

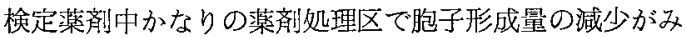
ら扎たが中でもベノミル水和剤，チ才ファネート水和剂

第 1 表 各薬郕の病葉における分生胞子形成阻止効果

\begin{tabular}{|c|c|c|c|c|c|c|c|}
\hline & 昭 & 44 & 年 & & 和 & 年 & \\
\hline 試 蒋 & 剤 & 濃 度 & $\begin{array}{l}\text { 炰子孟 } \\
\text { 形成量 }\end{array}$ & $\begin{array}{l}\text { 胞子形成 } \\
\text { 阻正率 }\end{array}$ & 供 試 薬 剂 & 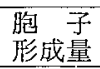 & $\begin{array}{l}\text { 暍子形成 } \\
\text { 阻 齿 } \\
\end{array}$ \\
\hline ダイホルタン & 水和 & 100 倍 & 3,802 & 42.4 & 之 ル 水和剂 1,000 倍 & 307 & 97.4 \\
\hline TPN & 水和 & 500 倍 & 3,755 & 43.1 & チオフアネート 水和刜 500儻 & 700 & 94.0 \\
\hline ETM & 水和 & 500 倍 & 1,504 & 77.2 & ジクロゾリン 水和骫 1,000 倍 & 13,670 & 0 \\
\hline ポリカーバメー & 卜水和 & 600 倍 & 3,435 & 47.9 & フォルペット 水和剤 500倍 & 7,924 & 47.1 \\
\hline$\ddot{*}$ ネ & 水和 & 600 倍 & 3,125 & 52.6 & カスミン $\mathrm{C}$ 水和剂 & 11,867 & 0 \\
\hline プロピネーブ & 水和 & 500 倍 & 5,205 & 21.1 & メチルチオファネート水和剤500倍 & 1,306 & 88.8 \\
\hline DDPP & 水和 & 剑 800 倍 & 3,674 & 44.3 & ホスベル乳凨 1,000 倍 & 6,836 & 41.3 \\
\hline ベ, & 水和 & 口剂 1,000 倍 & 181 & 97.2 & オリゼメ一ト 水和剤 500 倍 & 5,045 & 56.7 \\
\hline チオフォネート & 水和 & 口剂 500 倍 & 636 & 90.4 & グリセオフルビン水和剤 & 2,372 & 79.6 \\
\hline クフラムZ Z & 水和 & 600 倍 & 5,506 & 16.5 & キ;ンドー 水和剤 & 6,649 & 42.9 \\
\hline ボルドー & 液 & 4-4式 & 2,760 & 58.2 & ボルド 一 液 4-4式 & 7,127 & 38.8 \\
\hline PMF & 乳 & 剂 1,000 傍 & 186 & 97.2 & 乳 剂 1,000 倍 & 185 & 98.4 \\
\hline 無 & & 理 & 6,609 & - & 理 & 11,645 & - \\
\hline
\end{tabular}

